\title{
RESEARCH
}

Open Access

\section{Biocontrol potential of bacterial isolates from vermicompost and earthworm against the root-knot nematode Meloidogyne javanica infecting tomato plants}

Mahsa Rostami, Akbar Karegar *i and S. Mohsen Taghavi

\begin{abstract}
Background: Root-knot nematodes (Meloidogyne spp.) are the most destructive agricultural pests, which parasitize thousands of different plant species in the world. Using antagonistic bacteria can be a potential alternative to hazardous chemical nematicides. This study was conducted to evaluate the biocontrol activities of the bacteria isolated from vermicompost and earthworm against M. javanica in infected tomato plants.

Results: Seventeen bacteria were isolated from vermicompost and earthworm. Their antagonistic effects were tested against the root-knot nematode $M$. javanica in laboratory and in glasshouse experiments. In the preliminary screening test, 8 bacterial isolates significantly caused more than $50 \%$ decrease in reproduction factor (Rf) of the nematode on tomato plants. Six isolates with more than $60 \%$ reduction in the nematode $\mathrm{Rf}$ were selected and identified as follows: Lysinibacillus fusiformis C1, Bacillus megaterium C3, B. safensis WW3, Pseudomonas resinovorans WW4, Lysinibacillus sp. WW6, and Sphingobacterium daejeonense LV1 by 165 rRNA gene sequencing. The isolates $B$. megaterium C3, B. safensis WW3, P. resinovorans WW4, and L. fusiformis C1 inhibited the nematode egg hatching by 20-28\%, and Lysinibacillus sp. WW6 and L. fusiformis C1 caused 15 and 20\% mortality of the second-stage juveniles in vitro. In a glasshouse, the 6 bacterial isolates reduced the nematode Rf by $47-66 \%$, and P. resinovorans WW 4 was the most effective isolate. However, B. safensis WW3, B. megaterium C3, and L. fusiformis C1 had the best effect on plant growth.
\end{abstract}

Conclusions: Most of the bacteria isolated from earthworm or vermicompost had nematicidal properties. This study provided empirical evidence of the nematicidal potential of isolates Lysinibacillus fusiformis C1, Pseudomonas resinovorans WW4, and Sphingobacterium daejeonense LV1 and the antagonistic activities of Bacillus megaterium C3 and B. safensis WW3 against Meloidogyne javanica.

Keywords: Bacillus megaterium, Bacillus safensis, Biocontrol, Earthworm, Lysinibacillus fusiformis, Pseudomonas resinovorans, Sphingobacterium daejeonense

* Correspondence: karegar@shirazu.ac.ir

Department of Plant Protection, School of Agriculture, Shiraz University,

Shiraz 71441-65186, Iran

(c) The Author(s). 2021 Open Access This article is licensed under a Creative Commons Attribution 4.0 International License, which permits use, sharing, adaptation, distribution and reproduction in any medium or format, as long as you give appropriate credit to the original author(s) and the source, provide a link to the Creative Commons licence, and indicate if changes were made. The images or other third party material in this article are included in the article's Creative Commons licence, unless indicated otherwise in a credit line to the material. If material is not included in the article's Creative Commons licence and your intended use is not permitted by statutory regulation or exceeds the permitted use, you will need to obtain permission directly from the copyright holder. To view a copy of this licence, visit http://creativecommons.org/licenses/by/4.0/. 


\section{Background}

Root-knot nematodes (Meloidogyne spp.) are the most destructive agricultural pests, which parasitize many plant species of different groups around the world. They are the main subject of extensive research, including studies on biology, plant-nematode interaction, and especially control approaches (Moens et al. 2009). Many efforts have been made to find appropriate alternatives to environmentally harmful nematicides in the management of plant-parasitic nematodes (Oka et al. 2000).

Many parasitic and non-parasitic species of rhizobacteria are able to decrease the nematode population (Siddiqui and Mahmood 1999). Bacteria affect plantparasitic nematodes directly or indirectly via producing secondary metabolites and toxins or inducing systemic resistance in the plant (Mhatre et al. 2019).

The plant growth-promoting genera Azotobacter, Bacillus, Serratia, and Pseudomonas not only improve the plant growth but also contribute to nematode management (Wani 2015). Bacillus pumilus, Paenibacillus castaneae, and Mycobacterium immunogenum affected $M$. incognita in a greenhouse experiment by reducing the number of eggs and nematode galls and increasing tomato plant growth (Cetintas et al. 2018). Most detrimental rhizobacteria affect plant-parasitic nematodes via different mechanisms (Siddiqui and Mahmood 1999). Antagonistic bacteria kill nematodes by producing antibiotics, enzymes including proteases and chitinases, toxins, and volatile compounds (Marin-Bruzos and Grayston 2019). In addition, plant growth-promoting rhizobacteria (PGPR) induced systemic resistance by increasing the activity of the defense gene, which caused the decrease in the level of root-knot nematode infection in tomato plants (Vigila et al. 2019). These bacteria have been extracted from various substrates including manure, compost, and soil.

Vermicompost and earthworms are rich sources of beneficial bacteria (Pathma and Sakthivel 2013). Application of earthworm in the soil increases population densities of the fluorescent pseudomonads and actinomycetes (Elmer 2009). Metagenomic analyses of intestinal bacterial flora of earthworms showed the presence of numerous bacteria species, generally belonging to Proteobacteria (Singh et al. 2015). Some of the bacteria frequently found in vermicompost include Azospirillum, Azotobacter, Bacillus, Enterobacter, Nitrobacter, Paenibacillus, Pseudomonas, and Spiroplasma (Pathma and Sakthivel 2013). Worm casts are a rich source of antagonistic bacteria that can suppress plant pathogens including parasitic nematodes (Pathma and Sakthivel 2012).

Some reports showed that vermicompost had the ability to suppress several groups of plant-parasitic nematodes (Renčo and Kováčik 2015; Xiao et al. 2016). To the best of our knowledge, there is no report on the nematicidal activity of the bacteria, extracted from vermicompost and earthworm. Therefore, this study was conducted to evaluate the effects of bacteria, which isolated from vermicompost and earthworm on the rootknot nematode Meloidogyne javanica in vitro and in the glasshouse.

\section{Methods}

In the present study, bacteria were isolated from the coelomic fluid of earthworm, vermicompost leachate, and vermiwash. In a preliminary experiment, the effect of the bacterial isolates on M. javanica on tomato plants in a glasshouse was investigated. Then, the effects of the most effective isolates on egg hatching, mortality of the second-stage juveniles (J2s) of the nematode in laboratory, and the nematode activity and growth indices of infected tomato plants in the glasshouse were investigated.

\section{Collection and inoculum of Meloidogyne javanica}

Severely cucumber galled roots with Meloidogyne sp. were collected from an infested greenhouse in Fars province, Iran. By using the single egg mass technique, the nematode was reared on tomato (Lycopersicon esculentum Mill. cv. Early Urbana) roots. The nematode was identified as $M$. javanica using specific primers of $M$. javanica, $M$. icognita, and $M$. arenaria (Dong et al. 2001). The nematode eggs were extracted from the galled roots using sodium hypochlorite (Hussey and Barker 1973). After washing with tap water, the infected roots were cut into $2-3-\mathrm{cm}$-long pieces and mixed with $0.5 \% \mathrm{NaOCl}$ in a blender. The roots were chopped in the blender for $30 \mathrm{~s}$ at low speed, followed by passing through 20-, 200-, and 500-mesh/in. sieves. Eggs on the 500 -mesh sieve were gently washed by water to free them from $\mathrm{NaOCl}$ and collected into a Petri dish.

\section{Isolation of bacteria}

Vermicompost of animal manure was prepared during 3 months of summer. Liquid vermicompost, vermiwash, and the coelomic fluid of the earthworm Eisenia fetida were applied to isolate the bacteria (Rostami et al. 2014). For preparing the liquid vermicompost, a vermicompost ruched bag $(100 \mathrm{~g})$ was immersed into the water bucket (1 l) for 2 days at room temperature. Then, the water bucket was aerated strongly by using an air pump for 1 day.

Vermiwash was obtained by adding $50 \mathrm{~g}$ earthworms to $500 \mathrm{ml}$ of warm water and kept at room temperature for $30 \mathrm{~min}$. Then, it was stirred by a glass rod for $3 \mathrm{~min}$ and centrifuged at $3000 \mathrm{rpm}$ for $10 \mathrm{~min}$ to separate and sediment insoluble portion (Rostami et al. 2014).

To obtain the coelomic fluid, $50 \mathrm{~g}$ earthworms were placed into a Petri dish containing a sterile saline 
solution (0.9\%) and then subjected to electric shock every $3 \mathrm{~s}$, using a 9-V battery. The obtained coelomic fluid was used to isolate bacteria (Rostami et al. 2014).

To isolate bacteria, $5 \mu \mathrm{l}$ of each of the 3 liquid sources was cultured on nutrient agar (NA) and incubated for $48 \mathrm{~h}$ at $28^{\circ} \mathrm{C}$.

\section{Preliminary evaluation of the bacterial isolates against Meloidogyne javanica}

The inhibitory effects of 17 bacteria isolated from vermicompost leachate, vermiwash, and the earthworm coelomic fluid on $M$. javanica activities were studied in a glasshouse. The seeds of tomato (cv. Early Urbana) were sown in $19-\mathrm{cm}^{-}$diameter plastic pots containing $3 \mathrm{~kg}$ pasteurized mixed soil (field soil and river sand, 1:2); $40 \mathrm{mg}$ $\mathrm{P}(\mathrm{kg} \text { soil })^{-1}$ equivalent to $250 \mathrm{mg}$ triple super phosphate and $60 \mathrm{mg} \mathrm{N}$ (kg soil) ${ }^{-1}$ equivalent to $360 \mathrm{mg}$ potassium nitrate were applied to the soil at sowing. Plants at the four-leaf stage were inoculated with $20 \mathrm{ml}$ of bacteria suspensions $\left(10^{8} \mathrm{CFU} / \mathrm{ml}\right)$ per pot. Three days later, the tomato seedlings were inoculated with 6000 eggs of the root-knot nematode by adding the eggs to small holes made in the soil around the roots. The pots were placed on a glasshouse bench at $25-30{ }^{\circ} \mathrm{C}$ in a completely randomized design with 4 replicates. The pots were observed daily and watered as needed. Ninety days after nematode inoculation, the plants were harvested and their fresh root weights were measured. Then, the nematode second-stage juveniles (J2s) in a 100-g mixed soil sample of each pot were extracted by the Whitehead and Hemming tray method (Whitehead and Hemming 1965). In addition, the number of galls and egg masses in $1 \mathrm{~g}$ of roots of each plant were counted after staining with fuchsin acid. Moreover, the eggs in $1 \mathrm{~g}$ of root were extracted and counted. Then, the final population (Pf) and the reproduction factor (Rf) of $M$. javanica were calculated $(\mathrm{Rf}=\mathrm{Pf} / \mathrm{Pi})$.

After the preliminary experiment, the effects of the 6 selected bacterial isolates were investigated to evaluate their nematicidal ability against $M$. javanica. The conditions of the glasshouse experiment were the same as described in the preliminary experiment.

\section{In vitro evaluation of the nematicidal ability of the selected bacterial isolates}

Bacteria were cultured on NA and incubated for $48 \mathrm{~h}$ at $28^{\circ} \mathrm{C}$ in the incubator. To study their effects on the nematode egg hatching and juvenile mortality, about 100 eggs and $100 \mathrm{~J} 2 \mathrm{~s}$ per $1 \mathrm{ml}$ sterile water were added in separate $6-\mathrm{cm}$ Petri dishes. Then, $5 \mathrm{ml}$ of bacteria suspension $\left(10^{8} \mathrm{CFU} / \mathrm{ml}\right)$ were added. Distilled water was chosen as the control. After $48 \mathrm{~h}$, the dead J2s were counted, and after $72 \mathrm{~h}$, the unhatched eggs were counted (Cayrol et al. 1989). The experiment was carried out as a completely randomized design with 3 replicates.

\section{Statistical analysis}

Data of laboratory and glasshouse experiments were subjected to analysis of variance by the SAS 9.1 software. The comparison of means was done with Duncan's multiple range test $(P<0.05)$ (Duncan 1955).

\section{Identification of bacterial isolates}

The Gram reactions of bacterial isolates were determined by the $3 \% \mathrm{KOH}$ test (Schaad et al. 2001). The isolates were cultured on King's B medium (KB) to detect fluorescein production (King et al. 1954), and their tolerance to $\mathrm{NaCl}$ was tested (Caton et al. 2004).

Bacterial DNA was extracted using the $\operatorname{Expin}^{\text {Ts }}$ Combo GP (GeneAll ${ }^{\oplus}$, Tic Tech Centre, Singapore) DNA extraction kit, following the protocol of the manufacturer. The quality and quantity of the DNAs were spectrophotometrically evaluated and adjusted to $50 \mathrm{ng} \mathrm{Ll}^{-1}$, using the Nanodrop ND-100 (Nanodrop Technologies, Waltham, MA, USA).

The complete $16 \mathrm{~S}$ rDNA was amplified using universal bacterial primers 27F (5'-AGAGTTTGATCCTGGC TCAG-3') and 1492R (5'-GGTTACCTTGTTACGACT T-3'). The reaction mixture was $1 \mu \mathrm{l}$ of DNA $(50 / \mu \mathrm{l})$, $1 \mu \mathrm{l}$ each of forward and reverse primers $(10 \mu \mathrm{M}), 10 \mu \mathrm{l}$ Ampliqon ${ }^{\oplus}$ Taq DNA Polymerase Master Mix Red (Ampliqon A/S, Odense, Denmark), and $7 \mu \mathrm{l}$ of doubledistilled water. The PCR was performed (Kumar et al. 2014). Then, the PCR products were subjected to sequencing (Microsynth Company, Switzerland).

The obtained sequences were analyzed by BLASTn (NCBI (http://blast.ncbi.nlm.nih.gov). The sequences of related species and genera were obtained from the GenBank database, and the phylogenetic analysis was carried out with MEGA version 7 (Kumar et al. 2016). The sequences were lined up by Clustal W (Larkin et al. 2007) and analyzed using the maximum likelihood method to make a phylogenetic tree showing the relationships among isolates with percentage bootstrap values based on 1000 replicates (Saitou 1988).

\section{Results}

Preliminary evaluation of the bacterial isolates against Meloidogyne javanica

The results of preliminary screening of the 17 bacterial isolates from vermicompost or earthworm showed that in all treatments, the number of galls per gram of infected tomato roots was significantly lower than the untreated control. Except for one, the other 16 isolates reduced the $\mathrm{Rf}$ of the nematode by 11.6 to $81.6 \%$. However, 8 out of 16 isolates significantly reduced the nematode $\mathrm{Rf}$ from 54.8 to $81.6 \%$, while 6 of them with 
more than $60 \%$ reduction were selected for further in vitro and glasshouse experiments (Table 1).

\section{In vitro evaluation of the nematicidal ability of the selected bacterial isolates}

The selected bacterial isolates affected egg hatching and J2 mortality of $M$. javanica differently. The egg hatching of the nematode in the presence of Lysinibacillus sp. (W6) and S. daejeonense LV1 was statistically similar to the control (water). However, B. megaterium C3, P. resinovorans VW4, B. safensis VW3, and $L$. fusiformis $\mathrm{C} 1$ significantly inhibited egg hatching of the nematode by 20 to $28 \%$. The effects of the bacterial isolates on J2 mortality were somewhat different from their effects on egg hatching. The greatest death of J2s happened in the presence of Lysinibacillus sp. (W6) and L. fusiformis C1.
The effects of $B$. megaterium $\mathrm{C} 3$ and $P$. resinovorans VW4 on J2s were statistically similar to the control. The isolates Lysinibacillus sp. (W6), L. fusiformis C1, B. safensis VW3, and S. daejeonense LV1 caused 10 to $20 \%$ J2 mortality (Fig. 1).

\section{Evaluation of the effects of selected bacteria on nematode indices and plant growth parameters of tomato infected with Meloidogyne javanica Plant growth indices}

All selected isolates, except $P$. resinovorans VW4, significantly $(P \leq 0.05)$ improved shoot fresh and dry weights of the uninfected tomato plants (Table 2). B. safensis $V W 3, B$. megaterium C3, and L. fusiformis C1 significantly increased both shoot fresh and dry weights of the infected tomato plants. In addition, S. daejeonense LV1

Table 1 Screening the effects of 17 bacterial isolates from vermicompost and earthworm on the nematode indices of Meloidogyne javanica in the roots of tomato plants in a glasshouse

\begin{tabular}{|c|c|c|c|c|c|c|c|c|}
\hline $\begin{array}{l}\text { Bacterial } \\
\text { isolates }^{\mathrm{a}}\end{array}$ & $\begin{array}{l}\text { Galls } / g \\
\text { root }\end{array}$ & $\begin{array}{l}\text { Egg masses/g } \\
\text { root }\end{array}$ & $\begin{array}{l}\text { Eggs/g } \\
\text { root }\end{array}$ & $\begin{array}{l}\text { J2s/pot } \\
\text { soil }\end{array}$ & $\begin{array}{l}\text { Root fresh } \\
\text { weight (g) }\end{array}$ & $\begin{array}{l}\text { Final population } \\
(\mathrm{Pf})\end{array}$ & $\begin{array}{l}\text { Reproduction } \\
\text { factor (Rf) }\end{array}$ & $\begin{array}{l}\text { Rf reduction } \\
(\%)^{\mathbf{b}}\end{array}$ \\
\hline $\mathrm{C} 1$ & $183 \mathrm{~b}$ & $100 \mathrm{~d}-\mathrm{g}$ & $4238 \mathrm{~cd}$ & $5700 \mathrm{~g}$ & $6.00 b-f$ & $33,031 \mathrm{~cd}$ & $5.5 \mathrm{~cd}$ & 66.0 \\
\hline$C 2$ & $158 \mathrm{bc}$ & $122 c-g$ & 7744 b-d & $\begin{array}{l}18,000 \mathrm{a}- \\
\mathrm{d}\end{array}$ & $8.12 a b$ & $82,417 a b$ & $13.7 \mathrm{ab}$ & 15.3 \\
\hline C3 & $151 b c$ & $67 \mathrm{gf}$ & $2663 d$ & $\begin{array}{l}11,100 \mathrm{~b}- \\
\mathrm{g}\end{array}$ & $5.67 b-f$ & $26,424 b-d$ & $4.4 \mathrm{~b}-\mathrm{d}$ & 72.8 \\
\hline C6 & $123 \mathrm{bc}$ & $184 b-d$ & $7200 \mathrm{~b}-\mathrm{d}$ & $22,500 \mathrm{a}$ & $5.95 b-f$ & $65,865 a-c$ & $10.9 \mathrm{a}-\mathrm{c}$ & 32.3 \\
\hline $\mathrm{C} 8$ & $107 \mathrm{bc}$ & $164.5 \mathrm{~b}-\mathrm{e}$ & $12,338 \mathrm{ab}$ & $21,450 \mathrm{ab}$ & $6.00 \mathrm{~b}-\mathrm{f}$ & 97,487 a & $16.2 \mathrm{a}$ & 0.0 \\
\hline C9 & 148 bc & $149 c-f$ & $9225 b c$ & $\begin{array}{l}13,500 \mathrm{a}- \\
\mathrm{g}\end{array}$ & $8.12 \mathrm{ab}$ & $86,058 \mathrm{a}$ & $14.3 \mathrm{a}$ & 11.6 \\
\hline LV1 & $128 \mathrm{bc}$ & $50 \mathrm{~g}$ & $3300 \mathrm{~d}$ & 9975 d-g & $5.02 c-f$ & $27,930 \mathrm{~cd}$ & $4.6 \mathrm{~cd}$ & 71.3 \\
\hline LV2 & $110 \mathrm{bc}$ & $200 a-c$ & 9375 bc & $\begin{array}{l}17,100 a- \\
f\end{array}$ & $5.15 b-f$ & $58,271 \mathrm{a}-\mathrm{c}$ & $9.7 a-c$ & 40.1 \\
\hline LV3 & $131 b c$ & $140 c-f$ & $7650 \mathrm{~b}-\mathrm{d}$ & $\begin{array}{l}e^{17,700 a-} \\
\end{array}$ & $7.95 a-c$ & $81,350 \mathrm{ab}$ & $13.5 \mathrm{ab}$ & 16.4 \\
\hline LV5 & $113 b c$ & $172.5 \mathrm{~b}-\mathrm{e}$ & $6694 \mathrm{~cd}$ & $\begin{array}{l}15,900 \mathrm{a}- \\
\mathrm{g}\end{array}$ & $6.80 a-d$ & $62,962 a-c$ & $10.4 a-c$ & 35.3 \\
\hline LV6 & $158 b c$ & $154 \mathrm{~b}-\mathrm{e}$ & $6038 \mathrm{~cd}$ & $\begin{array}{l}15,750 \mathrm{a}- \\
\mathrm{g}\end{array}$ & $4.40 \mathrm{~d}-\mathrm{f}$ & $41,249 \mathrm{~cd}$ & $6.8 \mathrm{~cd}$ & 57.3 \\
\hline LV8 & $131 \mathrm{bc}$ & $235 a b$ & $8275 b-d$ & $\begin{array}{l}16,275 a- \\
g\end{array}$ & $6.62 \mathrm{a}-\mathrm{e}$ & $59,056 a-c$ & $9.8 a-c$ & 39.3 \\
\hline W2 & $175 b c$ & $205 a-c$ & $6435 \mathrm{~cd}$ & $\begin{array}{l}19,200 \mathrm{a}- \\
\mathrm{d}\end{array}$ & 3.65 ef & $43,931 \mathrm{~b}-\mathrm{d}$ & $7.3 \mathrm{~b}-\mathrm{d}$ & 54.8 \\
\hline W3 & $122 b c$ & $92 \mathrm{e}-\mathrm{g}$ & $5025 \mathrm{~cd}$ & $\begin{array}{l}10,275 \mathrm{~d}- \\
\mathrm{g}\end{array}$ & $4.90 \mathrm{~d}-\mathrm{f}$ & $36,393 \mathrm{~cd}$ & $6.0 \mathrm{~cd}$ & 62.6 \\
\hline W4 & $95 \mathrm{C}$ & $41 \mathrm{~g}$ & $3225 d$ & $6900 \mathrm{e}-\mathrm{g}$ & $5.77 b-f$ & $25,751 \mathrm{~cd}$ & $4.2 \mathrm{~cd}$ & 73.5 \\
\hline WW5 & $110 b c$ & $196.5 \mathrm{a}-\mathrm{c}$ & $6875 b-d$ & $\begin{array}{l}21,150 a- \\
c\end{array}$ & $9.15 \mathrm{a}$ & 85,636 a & $14.2 \mathrm{a}$ & 12.0 \\
\hline WW6 & $161 b c$ & $121 \mathrm{e}-\mathrm{g}$ & $3075 d$ & $6390 \mathrm{f}-\mathrm{g}$ & $3.55 f$ & $17,895 d$ & $2.9 \mathrm{~d}$ & 81.6 \\
\hline Water & $328 a$ & $275 a$ & 16,650 a & $\begin{array}{l}20,475 a- \\
d\end{array}$ & $4.35 d-f$ & 97,404 a & $16.2 \mathrm{a}$ & - \\
\hline
\end{tabular}




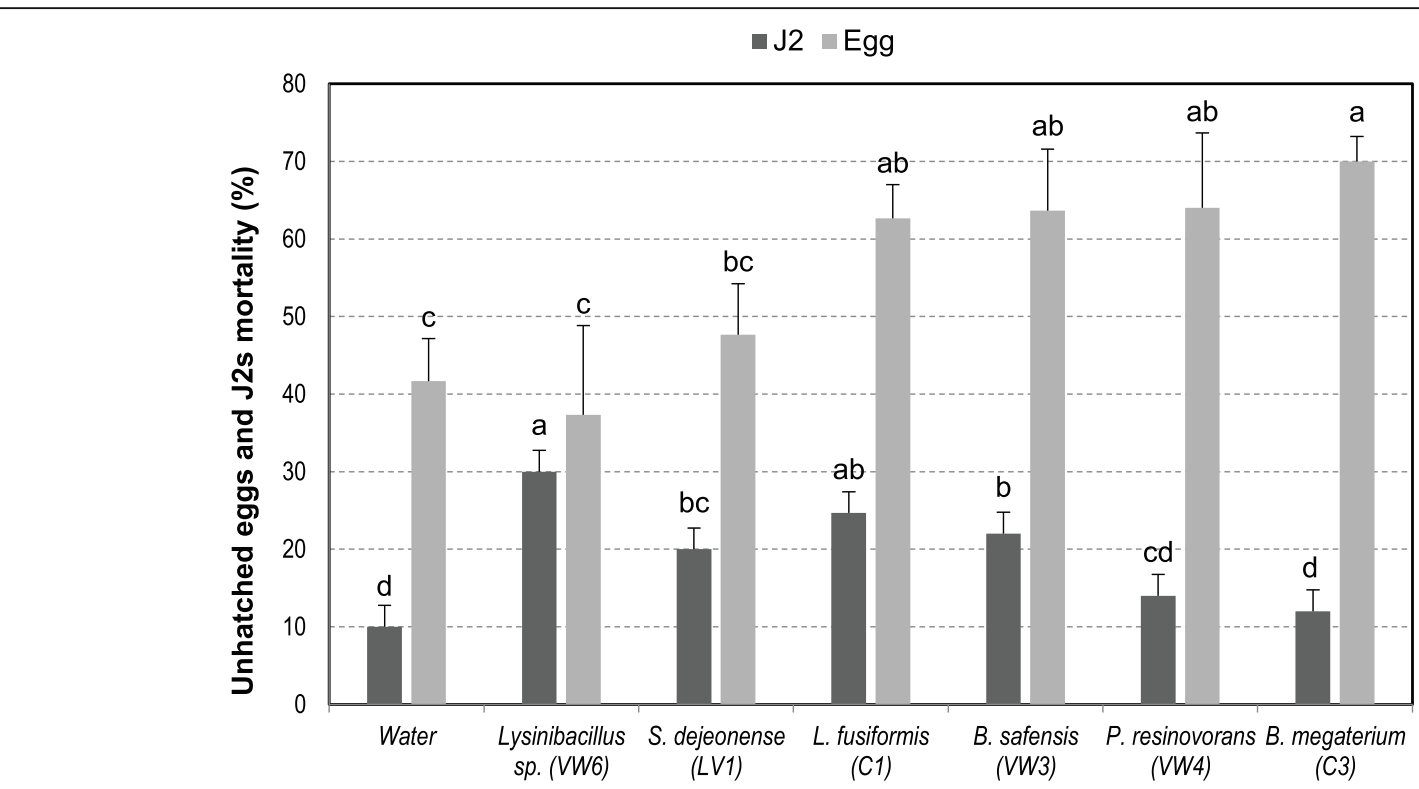

Fig. 1 Effect of bacteria isolates on egg hatching and mortality of the second-stage juveniles (J2s) of Meloidogyne javanica in vitro. Values in the same column followed by the same letter(s) are not significantly different $(P \leq 0.05)$, according to Duncan's multiple range test. Bars indicate the standard error of the means $(n=3)$

improved these indices, but its effect was less than the others. P. resinovorans VW4 only increased the shoot fresh weight of infected plants.

\section{Nematode indices}

The six bacterial isolates significantly decreased the number of galls, egg masses, and eggs per gram of root, and final population of the root-knot nematode (Table 3). The isolate $P$. resinovorans VW4 had the greatest effect on reducing the number of galls, egg masses, and eggs in the root system, and the nematode Rf. The selected bacterial isolates reduced the nematode Rf by $47-66 \%$.

\section{Molecular identification of bacterial isolates}

Identification of isolates was done by comparison of their 16S rDNA sequences with those deposited in the GenBank database. The 6 selected isolates were identified as Bacillus safensis VW3, Pseudomonas resinovorans VW4, Lysinibacillus sp. VW6, L. fusiformis C1, B. megaterium C3, and Sphingobacterium daejeonense LV1. The sequences of their 16s rDNA had been deposited in the GenBank (Table 4). The phylogenetic relationship among the identified bacterial isolates and the closely related species and genera has been shown in (Figs. 2 and 3).

$P$. resinovorans VW4 and $S$. daejeonense LV1 are gram-negative, but B. safensis VW3, B. megaterium C3,

Table 2 Effect of bacterial isolates on the growth of tomato plants infected by Meloidogyne javanica

\begin{tabular}{|c|c|c|c|c|c|}
\hline \multirow[t]{2}{*}{ Treatments } & \multicolumn{2}{|c|}{ Shoot fresh weight (g) } & \multicolumn{2}{|c|}{ Shoot dry weight (g) } & \multirow{2}{*}{$\begin{array}{l}\text { Root } \\
\text { fresh } \\
\text { weight } \\
\text { (g), with } \\
\text { nematode }\end{array}$} \\
\hline & With nematode & Without nematode & With nematode & Without nematode & \\
\hline Bacillus megaterium C3 & $29 a-c$ & $29 a-c$ & $3.47 a-c$ & $3.90 \mathrm{a}-\mathrm{d}$ & $7.17 \mathrm{a}$ \\
\hline Bacillus safensis WW3 & $35 \mathrm{a}$ & $35 \mathrm{a}$ & $4.72 \mathrm{ab}$ & $5 a$ & 4.27 a \\
\hline Lysinibacillus fusiformis C1 & $25 a-d$ & $30 \mathrm{ab}$ & $3.77 \mathrm{a}-\mathrm{d}$ & $3.85 \mathrm{a}-\mathrm{d}$ & $4.10 \mathrm{a}$ \\
\hline Lysinibacillus sp. W6 & $17 c-e$ & $32 \mathrm{a}$ & $2.25 d-f$ & $3.50 \mathrm{a}-\mathrm{c}$ & $4.05 \mathrm{a}$ \\
\hline Pseudomonas resinovorans WW4 & $18 b-d$ & $27 \mathrm{a}-\mathrm{d}$ & $2.52 \mathrm{~d}-\mathrm{f}$ & $3.02 \mathrm{de}$ & $5.47 \mathrm{a}$ \\
\hline Sphingobacterium daejeonense LV1 & $23 a-d$ & $35 \mathrm{a}$ & $1.90 \mathrm{e}$ & $4.82 \mathrm{a}$ & $4.62 \mathrm{a}$ \\
\hline Water & $8.65 \mathrm{e}$ & $13 d$ & $1.27 \mathrm{f}$ & $1.75 \mathrm{e}$ & $4.58 \mathrm{a}$ \\
\hline
\end{tabular}

Data are the means of 4 replicates. Values in the same column followed by the same letter(s) are not significantly different $(P \leq 0.05)$, according to Duncan's multiple range test 
Table 3 Effects of six selected bacterial isolates on nematode indices of Meloidogyne javanica on tomato roots in a glasshouse

\begin{tabular}{|c|c|c|c|c|c|c|c|}
\hline Treatments & $\begin{array}{l}\text { Galls/g } \\
\text { root }\end{array}$ & $\begin{array}{l}\text { Egg masses/g } \\
\text { root }\end{array}$ & $\begin{array}{l}\text { Eggs/g } \\
\text { root }\end{array}$ & $\begin{array}{l}\text { J2s/pot } \\
\text { soil }\end{array}$ & $\begin{array}{l}\text { Final population } \\
\text { (Pf) }\end{array}$ & $\begin{array}{l}\text { Reproduction factor } \\
\text { (Rf) }\end{array}$ & $\begin{array}{l}\text { Rf reduction } \\
(\%)^{\mathrm{a}}\end{array}$ \\
\hline Bacillus megaterium $\mathrm{C} 3$ & $110 \mathrm{bc}$ & $127 b$ & $4475 b c$ & $8850 \mathrm{~b}$ & $38,260 \mathrm{~b}$ & $6.3 b$ & 47.2 \\
\hline Bacillus safensis WW3 & $119 \mathrm{bc}$ & $117 \mathrm{bc}$ & $5825 b$ & $8100 \mathrm{~b}$ & $32,957 \mathrm{~b}$ & $5.4 \mathrm{~b}$ & 54.5 \\
\hline Lysinibacillus fusiformis C1 & $141 \mathrm{~b}$ & $67 \mathrm{~cd}$ & $7875 \mathrm{bc}$ & $4500 \mathrm{~b}$ & $36,798 b$ & $6.1 \mathrm{~b}$ & 49.2 \\
\hline Lysinibacillus sp. WW6 & $123 \mathrm{bc}$ & $133 \mathrm{~b}$ & $5525 \mathrm{bc}$ & $5850 \mathrm{~b}$ & $28,730 \mathrm{~b}$ & $4.7 \mathrm{~b}$ & 60.3 \\
\hline $\begin{array}{l}\text { Pseudomonas resinovorans } \\
\text { W4 }\end{array}$ & $72 c$ & $48 d$ & $3738 c$ & $6300 \mathrm{~b}$ & $24,615 b$ & $4.1 \mathrm{~b}$ & 66.0 \\
\hline $\begin{array}{l}\text { Sphingobacterium } \\
\text { daejeonense LV1 }\end{array}$ & $122 \mathrm{bc}$ & $50 d$ & 5529 bc & $6320 \mathrm{~b}$ & $33,765 b$ & $5.6 \mathrm{~b}$ & 53.4 \\
\hline Water & $251 \mathrm{a}$ & $216 a$ & 11,400 a & 15,900 a & 72,526 a & $12.0 \mathrm{a}$ & - \\
\hline
\end{tabular}

Data are the means of 4 replicates. Values in the same column followed by the same letter(s) are not significantly different $(P \leq 0.05)$, according to Duncan's multiple range test

aPercentage of the nematode reproduction factor reduction compared to the control

Lysinibacillus sp. VW6, and L. fusiformis C1 are grampositive. None of them could produce fluorescein on King's B medium. While all isolates grow on medium with $2 \% \mathrm{NaCl}$, but only B. safensis VW3 tolerate $10 \%$ $\mathrm{NaCl}$ (Table 4).

\section{Discussion}

Antagonistic bacteria against the M. javanica were isolated from liquid vermicompost, coelomic fluid of earthworm, and vermiwash, which were chosen as the rich source of bacteria. The most effective isolates belonging to the genera Bacillus, Lysinibacillus, Pseudomonas, and Sphingobacterium. The nematicidal activity and their stimulating effects on plant growth of some isolates of these genera have already been studied and shown. However, the effects of some isolates of the present study have not been previously demonstrated.

The genus Bacillus includes many species, which mostly isolated from soil and exhibit plant-promoting traits. The controlling effects of several species including B. cereus, B. subtilis, and B. megaterium on plantparasitic nematodes have been shown in many studies
(Saikia et al. 2013), and Engelbrecht et al. (2018) summarized their usefulness as natural enemies of root-knot nematodes, their nematicidal activities, and their mode of action as biocontrol agents. In the present study, the isolates B. megaterium C3 and B. safensis VW3 improved the growth parameters of the nematode infected and healthy tomato plants. Moreover, they reduced the nematode Rf by 72.8 and $62.6 \%$ in the first screening and 47.2 and $54.5 \%$ in the second selected isolates glasshouse experiments. The extent of this effect changed in the second experiment, but significantly, both Bacillus isolates reduced the nematode indices. The second experiment can confirm that by repeating the experiment, these bacteria were still effective in controlling nematode damage.

The effect of B. safensis VW3 on the plant growth parameter and the nematode indices was slightly better than B. megaterium $\mathrm{C} 3$. On the other hand, both species significantly inhibited the nematode egg hatching, but only B. safensis VW3 caused $\mathrm{J} 2$ mortality.

Strains of $B$. safensis had the ability to produce amylase, chitinase, keratinase, lipase, protease, and some

Table 4 The bacterial isolates from liquid vermicompost, vermiwash, or the coelomic fluid of earthworm, and their accession numbers of their 165 rDNA sequences deposited in the GenBank database

\begin{tabular}{|c|c|c|c|c|c|c|c|c|}
\hline Bacterial isolates & Sources & $\begin{array}{l}\text { Gram } \\
\text { reaction }\end{array}$ & $\begin{array}{l}\text { Fluorescence on } \\
\text { King's medium B }\end{array}$ & $\begin{array}{l}2 \% \mathrm{NaCl} \\
\text { tolerance }\end{array}$ & $\begin{array}{l}5 \% \mathrm{NaCl} \\
\text { tolerance }\end{array}$ & $\begin{array}{l}7 \% \mathrm{NaCl} \\
\text { tolerance }\end{array}$ & $\begin{array}{l}10 \% \mathrm{NaCl} \\
\text { tolerance }\end{array}$ & $\begin{array}{l}\text { Accession } \\
\text { no. }\end{array}$ \\
\hline $\begin{array}{l}\text { Bacillus megaterium } \\
\text { C3 }\end{array}$ & $\begin{array}{l}\text { Coelomic } \\
\text { fluid }\end{array}$ & + & - & + & + & + & - & MN560028 \\
\hline Bacillus safensis WW3 & Vermiwash & + & - & + & + & + & + & MN560025 \\
\hline $\begin{array}{l}\text { Lysinibacillus fusiformis } \\
\text { C1 }\end{array}$ & $\begin{array}{l}\text { Coelomic } \\
\text { fluid }\end{array}$ & + & - & + & + & + & - & MN560027 \\
\hline Lysinibacillus sp. WW6 & Vermiwash & + & - & + & + & - & - & MN560026 \\
\hline $\begin{array}{l}\text { Pseudomonas } \\
\text { resinovorans WW4 }\end{array}$ & Vermiwash & - & - & + & - & - & - & MN559969 \\
\hline $\begin{array}{l}\text { Sphingobacterium } \\
\text { daejeonense LV1 }\end{array}$ & $\begin{array}{l}\text { Liquid } \\
\text { vermicompost }\end{array}$ & - & - & + & - & - & - & MN559970 \\
\hline
\end{tabular}




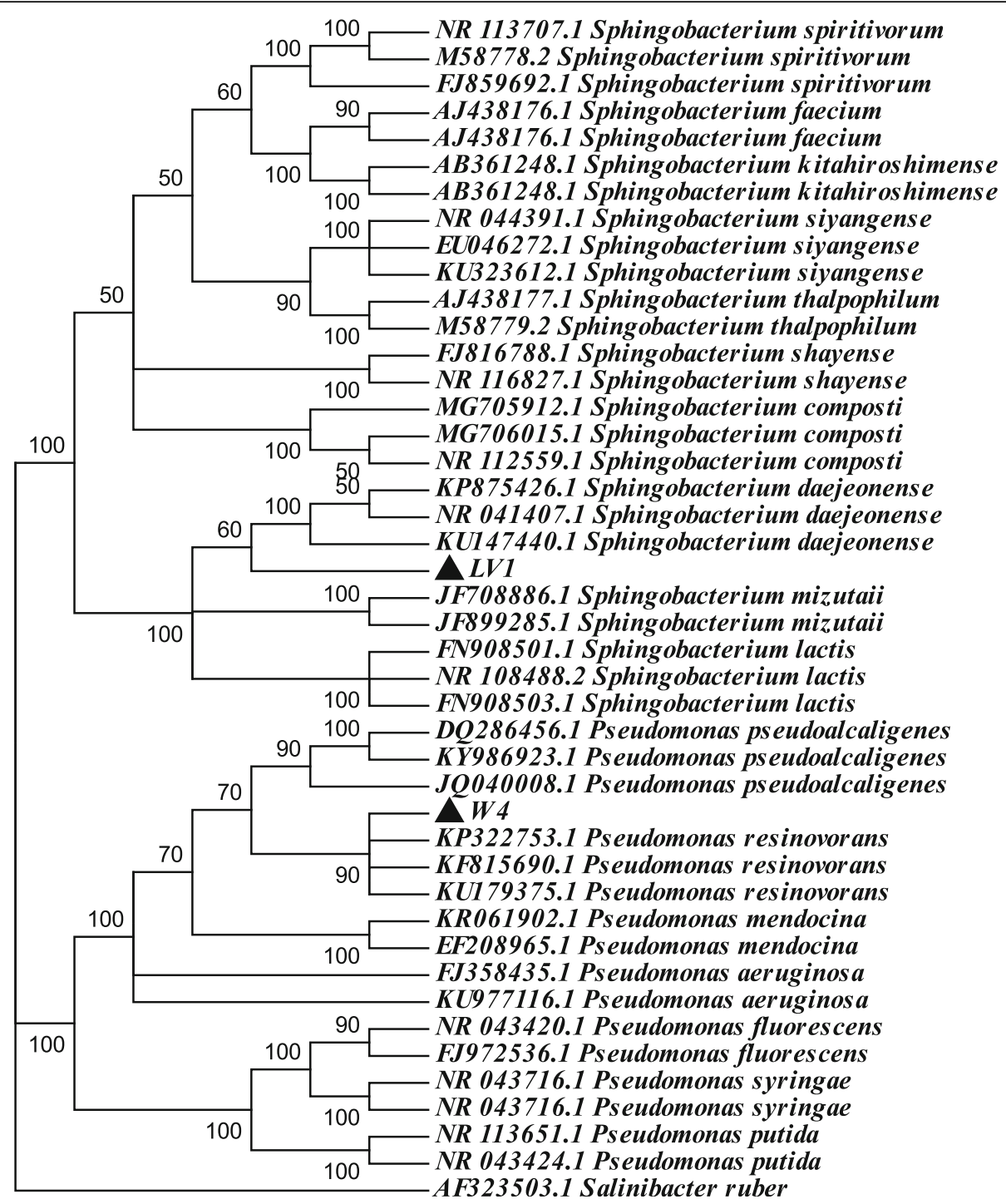

Fig. 2 Phylogenic relationships of Pseudomonas resinovorans (W4) and Sphingobacterium daejeonense (LV1) based on 165 rDNA sequences (maximum likelihood method). Numbers on the branches indicate bootstrap values. Salinibacter ruber was used as a root

other enzymes (Lateef et al. 2015a). B. safensis can promote plant growth (Lateef et al. 2015b), and this feature has been shown in several studies. B. safensis R173 and B. megaterium R181 along with two other strains, which isolated from the wheat rhizosphere, were the most efficient strains on corn growth in greenhouse pot test (Akinrinlola et al. 2018). In two simultaneous studies, the nematicidal activity of $B$. safensis has been demonstrated. The results of an in vitro screening of plant growth-promoting rhizobacteria (PGPR) indicated that three strains Bsa25, Bsa26, and Bsa27 of B. safensis and 12 other species of Bacillus caused greater than $50 \% \mathrm{H}$. glycines $\mathrm{J} 2$ mortality. In addition, the strain B. safensis Bsa27 decreased the number of $H$. glycines cysts at 60 days after planting in a field experiment (Xiang et al. 2017a). In another study, Xiang et al. (2017b) reported that strains of B. safensis, such as Bsa26 caused 53.7 to $100 \%$, mortality of $M$. incognita J2s, and B. safensis along with other Bacillus species showed antagonistic activity against M. incognita. As shown in this study, B. safensis isolate was able to reduce the population of root-knot nematode.

B. megaterium is an aerobic and large-cell bacterium, which was found in soil and several plant tissues as an endophyte. Some of its isolates involved in chitin degradation, nitrogen fixation, or solubilization of insoluble phosphates (Logan and De Vos 2015). An endophytic isolate of $B$. megaterium, which was found in root 


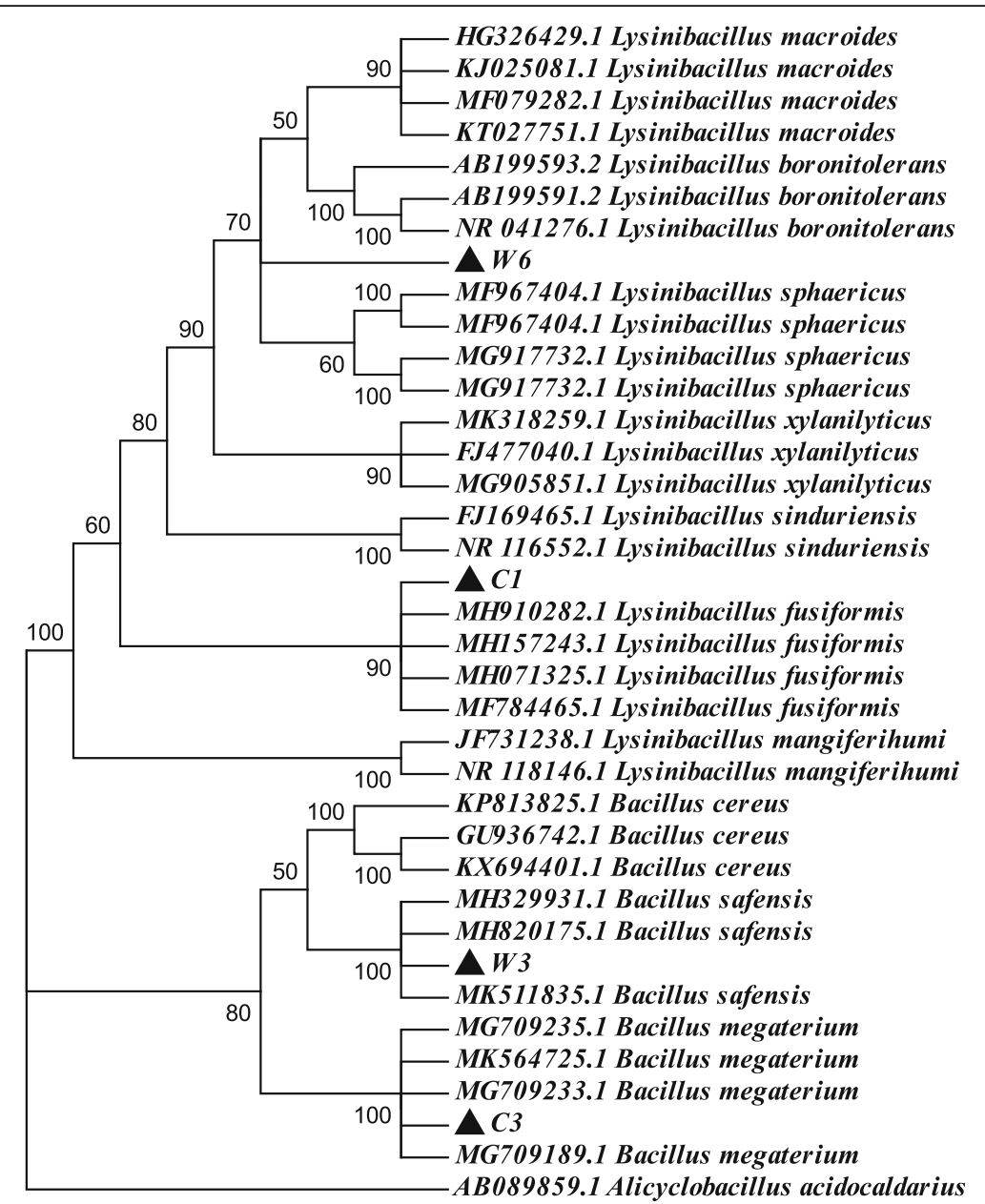

Fig. 3 Phylogenic relationships of Bacillus spp. (B. megaterium C3 and B. safensis WW3) and Lysinibacillus spp. (L. fusiformis C1 and Lysinibacillus sp. WW6) based on 165 rDNA sequences (maximum likelihood method). Numbers on the branches indicate bootstrap values. Alicyclobacillus

acidocaldarius was used as a root

nodules of Medicago polymorpha, was able to produce indole acetic acid (IAA) (Chinnaswamy et al. 2018). In addition, an isolate of $B$. megaterium reduced migration of M. graminicola to the root zone of rice plants and its root penetration (Padgham and Sikora 2007). Huang et al. (2010) showed that the strain B. megaterium YMF3.25 reduced egg hatching and infection of $M$. incognita by producing nematicidal volatiles. The results of an experiment indicated that five isolates of Bacillus out of 34 strains of endophytic bacteria, which isolated from healthy roots of black pepper, caused $100 \%$ mortality of Meloidogyne sp. J2s in vitro. Of these selective strains, B. megaterium DS9 significantly reduced the nematode populations in soil and roots of infected pepper plants by $81.86 \%$ and $73.11 \%$, respectively, in a greenhouse (Tran et al. 2019).

The effects of $B$. safensis VW3 and B. megaterium C3 on egg hatching could be related to their ability to produce chitinase. The eggshell is the only structure of the nematode that contains chitin. Both species are PGPR and can improve plant growth and are nematicidal. It has been shown that there was a positive correlation between the chitinase production and nematicidal abilities of the bacterial strains and their effect on the plant growth parameters (AbdelSalam et al. 2018).

In the present study, 2 isolates of Lysinibacillus showed nematicidal activity. L. fusiformis C1 isolated from coelomic fluid of earthworm and Lysinibacillus sp. VW6 from vermiwash. L. fusiformis $\mathrm{C} 1$ caused 66 and $49.2 \%$, and Lysinibacillus sp. VW6 $81.6 \%$ and $60.3 \%$ reduction the nematode Rf, respectively in the first screening and second selected isolates glasshouse experiments. Both isolates caused the greatest death rate of $M$. javanica J2s in vitro by 15 and $20 \%$, respectively, but only $L$. fusiformis $\mathrm{C} 1$ significantly inhibited the nematode egg hatching by $21 \%$ and improved the infected tomato plant growth parameters. 
Several species of the genus Lysinibacillus reported having nematicidal activity. L. mangiferahumi, which was separated from the soil around the roots of mango, produced nematicidal volatile compounds against $M$. incognita (Yang et al. 2012). It was reported that $L$. macroides caused $64.8 \%$ mortality of $M$. incognita J2s in a laboratory trial (Xiang et al. 2017b). As far as we know, the nematicidal activity of L. fusiformis has not been reported yet. Singh et al. (2013) demonstrated that the strain L. fusiformis B-CM18, which was collected from chickpea rhizosphere and has the ability to produce chitinase, possesses antifungal activity against different fungal pathogens. L. fusiformis $\mathrm{C} 1$, which inhibited egg hatching of $M$. javanica, is likely to produce chitinase.

Another bacterium with inhibitory effect on $M$. javanica activities in the present study was Pseudomonas resinovorans VW4, which was isolated from vermiwash. It caused the greatest reduction in galls and egg masses number and reduced nematode Rf by 73.5 and $66.0 \%$ in the first screening and second selected isolates experiments, respectively. Moreover, it inhibited 22\% egg hatch of $M$. javanica, but did not affect $\mathrm{J} 2$ mortality and the growth parameters of infected tomato plants.

Many Pseudomonas species promote plant growth, induce resistance, and have the ability to protect the plant against pathogens (Preston 2004; Osman et al. 2011). P. aeruginosa is a plant growth-promoting rhizobacterium, which its nematicidal effects on root-knot nematodes were reported. Siddiqui and Ehteshamul-Haque (2001) reported that $P$ aeruginosa $\mathrm{IE}-6 \mathrm{~S}^{+}$reduced the population of $M$. javanica in soil and infected tomato roots. This isolate was able to produce hydrogen cyanide $(\mathrm{HCN})$. Two other isolates of this bacterium, Pa8 and $\mathrm{Pa} 9$, reduced egg hatching of $M$. incognita, increased the tomato plant growth, decreased the galls number and nematode reproduction in a glasshouse test, and produced a great amount of HCN and IAA (Singh and Siddiqi 2010). The nematicidal effects of the Antarctic strain P. putida $1 \mathrm{~A} 00316$ on M. incognita, showed in the pot and in vitro experiments, indicated that this strain could increase the activities of phenylalanine ammonia lyase, polyphenol oxidase, and peroxidase as defense enzymes, and induce systematic resistance in tomato plants (Tang et al. 2014). In addition, it was shown that 7 volatile compounds of strain 1A00316 had nematicidal activity against $M$. incognita $\mathrm{J} 2 \mathrm{~s}$ and inhibited its egg hatching when used directly or as a fumigant (Zhai et al. 2018). Although the nematicidal potential of several species of Pseudomonas has been demonstrated, there is no report recorded concerning the nematicidal activity of $P$. resinovorans.

In the present study, S. daejeonense LV1, which was isolated from liquid vermicompost, showed the nematicidal effect on $M$. javanica and caused 71.3 and $53.4 \%$ reduction in the nematode $\mathrm{Rf}$ respectively in the first and second glasshouse experiments. It caused M. javanica $\mathrm{J} 2$ mortality and improved the growth parameters of healthy and infected tomato plants but did not affect the egg hatching. Although there are no reports concerning the nematicidal activity of $S$. daejeonense, the effect of other species on plant-parasitic nematodes has been demonstrated. S. nematocida, the endophyte bacterium, which has been isolated from the fresh leaf of Nicotiana tabacum in China (Liu et al. 2012), caused $100 \%$ mortality of juveniles and inhibited 100\% egg hatching of $M$. incognita (Xi et al. 2013). In addition, it was shown that Sphingobacterium sp. CIGBTb produced chitinase and had nematicidal effects on root-knot nematodes (Sánchez Ortiz et al. 2018).

\section{Conclusions}

Most of the bacteria isolated from earthworm or vermicompost had nematicidal activities. The bacterial isolates Bacillus megaterium C3, B. safensis VW3, Lysinibacillus sp. VW6, L. fusiformis C1, Pseudomonas resinovorans VW4, and Sphingobacterium daejeonense LV1 showed biocontrol potentials against the root-knot nematode $M$. javanica in the infected tomato plant. Moreover, the isolates B. megaterium C3, B. safensis VW3, and L. fusiformis $\mathrm{C} 1$ improved the growth parameters of tomato plants. The nematicidal activities of isolates $L$. fusiformis $\mathrm{C} 1, P$. resinovorans VW4, and $S$. daejeonense LV1 and the antagonistic activities of $B$. megaterium $\mathrm{C} 3$ and $B$. safensis VW3 against $M$. javanica are first documented in this study. Further studies to investigate the nematicidal effects of the bacteria under field conditions and their mode of actions are needed.

\section{Abbreviations \\ HCN: Hydrogen cyanide; IAA: Indole acetic acid; J2: Second-stage juvenile; Pf: Final population; PGPR: Plant growth-promoting rhizobacteria; Pi: Initial population; Rf: Reproduction factor}

\section{Acknowledgements \\ The authors gratefully acknowledge the financial support of the Shiraz University and Iran National Science Foundation (INSF). In addition, thanks are expressed to Miss Nasim Sedighian, Department of Plant Protection, School of Agriculture, Shiraz University, Shiraz, Iran, for her technical assistance.}

\section{Authors' contributions}

The first and second authors, MR and AK, are responsible for conducting the experimental work and analysis interpretation of the data. The second author, AK, is responsible for designing and supervising the study and revising the paper scientifically. The third author, SMT, is responsible for the bacterial identification and contribution to the study. All authors read and approved the final manuscript.

\section{Authors' information}

The first author is a Ph.D. candidate of Plant Pathology (Nematology). The second author is a professor of plant pathology (Nematology), and the third author is a professor of plant pathology (Bacteriology) at Shiraz University. 


\section{Funding}

This research was funded by the Shiraz University and Iran National Science Foundation (INSF) (No. 97011428). The cost of the greenhouse test was provided by Shiraz University, and the cost of laboratory study and molecular identification of bacteria was provided by INSF.

\section{Availability of data and materials}

The samples of vermicompost, bacteria, and tomato seed, used in this study, are available in the Nematode Laboratory, Department of Plant Protection, School of Agriculture, Shiraz University, Shiraz, Iran. The datasets generated and/or analyzed during the current study are not publicly available because that the data and material are included in the dissertation of the first author and have not yet been published formally but are available from the corresponding author upon request. Accession no. of the identified bacteria are available in the NCBI database.

\section{Ethics approval and consent to participate}

The authors declare that the present article is part of the result of the research project of the first author's doctoral dissertation, which has been approved by the Vice Chancellor for Education and Postgraduate Studies of Shiraz University. In addition, they declare that all the relevant ethics issues have been considered in conducting the research and writing the manuscript.

\section{Consent for publication}

Not applicable.

\section{Competing interests}

The authors declare that they have no conflict of interest.

Received: 26 November 2020 Accepted: 12 February 2021 Published online: 19 February 2021

\section{References}

Abdel-Salam MS, Ameen HH, Soliman GM, Elkelany US, Asar AM (2018) Improving the nematicidal potential of Bacillus amyloliquefaciens and Lysinibacillus sphaericus against the root-knot nematode Meloidogyne incognita using protoplast fusion technique. Egypt J Biol Pest Control 28:31. https://doi.org/1 0.1186/s41938-018-0034-3

Akinrinlola RJ, Yuen GY, Drijber RA, Adesemoye AO (2018) Evaluation of Bacillus strains for plant growth promotion and predictability of efficacy by in vitro physiological traits. Int J Microbiol Article ID 5686874. https://doi.org/10.11 55/2018/5686874

Caton TM, Witte LR, Ngyuen HD, Buchheim JA, Buchheim MA, Schneegurt MA (2004) Halotolerant aerobic heterotrophic bacteria from the Great Salt Plains of Oklahoma. Microb Ecol 48:449-462. https://doi.org/10.1007/s00248-0040211-7

Cayrol JC, Djian C, Pijarowski L (1989) Study of the nematicidal properties of the culture filtrate of the nematophagous fungus Paecilomyces lilacinus. Revue Nématol 12:331-336 https://horizon.documentation.ird.fr/exl-doc/pleins_ textes/pleins_textes_5/pt5/nemato/27861.pdf

Cetintas R, Kusek M, Fateh SA (2018) Effect of some plant growth-promoting rhizobacteria strains on root-knot nematode, Meloidogyne incognita, on tomatoes. Egypt J Biol Pest Control 28:7. https://doi.org/10.1186/s41938-0170008-x

Chinnaswamy A, Coba de la Peña T, Stoll A, de la Peña RD, Bravo J, Rincón A, Lucas MM, Pueyo JJ (2018) A nodule endophytic Bacillus megaterium strain isolated from Medicago polymorpha enhances growth, promotes nodulation by Ensifer medicae and alleviates salt stress in alfalfa plants. Ann Appl Biol 172:295-308. https://doi.org/10.1111/aab.12420

Dong K, Dean RA, Fortnum BA, Lewis SA (2001) Development of PCR primers to identify species of root-knot nematodes: Meloidogyne arenaria, M. hapla, M. incognita and M. javanica. Nematropica 31:271-280 https://journals.flvc.org/ nematropica/article/view/69633

Duncan DB (1955) Multiple range and multiple F tests. Biometrics 11:1-42

Elmer WH (2009) Influence of earthworm activity on soil microbes and soil borne diseases of vegetables. Plant Dis 93:175-179. https://doi.org/10.1094/PDIS93-2-0175

Engelbrecht G, Horak I, Jansen van Rensburg PJ, Claassens S (2018) Bacillus-based bionematicides: development, modes of action and commercialization.
Biocontrol Sci Techn 28:629-653. https://doi.org/10.1080/09583157.2018.14 69000

Huang Y, Xu C, Ma L, Zhang K, Duan C, Mo MH (2010) Characterisation of volatiles produced from Bacillus megaterium YFM3.25 and their nematicidal activity against Meloidogyne incognita. Eur J Plant Pathol 126:417-422. https://doi.org/10.1007/s10658-009-9550-z

Hussey RS, Barker KR (1973) A comparison of methods of collecting inocula of Meloidogyne spp., including a new technique. Plant Dis Rep 57:1025-1028

King EO, Ward MK, Raney DE (1954) Two simple media for the demonstration of pyocyanin and fluorescin. J Lab Clin Med 44:301-307

Kumar S, Stecher G, Tamura K (2016) MEGA7: molecular evolutionary genetics analysis version 7.0 for bigger datasets. Mol Bio Evol 33:1870-1874. https:// doi.org/10.1093/molbev/msw054

Kumar SN, Mohandas C, Nambisan B (2014) Purification, structural elucidation and bioactivity of tryptophan containing diketopiperazines, from Comamonas testosteroni associated with a rhabditid entomopathogenic nematode against major human-pathogenic bacteria. Peptides 53:48-58. https://doi.org/10.1016/j.peptides.2013.09.019

Larkin MA, Blackshields G, Brown NP, Chenna R, McGettigan P, McWilliam H, Thompson JD (2007) Clustal W and Clustal X version 2.0. Bioinformatics 23: 2947-2948. https://doi.org/10.1093/bioinformatics/btm404

Lateef A, Adelere IA, Gueguim-Kana EB (2015a) The biology and potential biotechnological applications of Bacillus safensis. Biologia 70:411-419. https:// doi.org/10.1515/biolog-2015-0062

Lateef A, Adelere IA, Gueguim-Kana EB (2015b) Bacillus safensis LAU 13: a new novel source of keratinase and its multi-functional biocatalytic applications. Biotechnol Biotec Eq 29:54-63. https://doi.org/10.1080/13102818.2014.986360

Liu J, Yang LL, Xu CK, Xi JQ, Yang FX, Zhou F, Zhou Y, Mo MH, Li WJ (2012) Sphingobacterium nematocida sp. nov., a nematicidal endophytic bacterium isolated from tobacco. Int J Syst Evol Microbiol 62:1809-1813. https://doi. org/10.1099/ijs.0.033670-0

Logan NA, De Vos P (2015) Bacillus. In: Whitman WB (ed) Bergey's Manual of Systematics of Archaea and Bacteria. John Wiley \& Sons, Hoboken, NJ. https://doi.org/10.1002/9781118960608.gbm00530

Marin-Bruzos M, Grayston SJ (2019) Biological control of nematodes by plant growth-promoting rhizobacteria: secondary metabolites involved and potential applications. In: Singh HB, Keswani C, Reddy MS, Sansinenea E, García-Estrada C (eds) Secondary metabolites of plant growth promoting rhizomicroorganisms. Springer, Singapore

Mhatre PH, Karthik C, Kadirvelu K, Divya KL, Venkatasalam EP, Srinivasan S, Shanmuganathan R (2019) Plant growth promoting rhizobacteria (PGPR): a potential alternative tool for nematodes bio-control. Biocatal Agri Biotechnol 17:119-128. https://doi.org/10.1016/j.bcab.2018.11.009

Moens M, Perry RN, Starr 」L (2009) Meloidogyne species - a diverse group of novel and important plant parasites. In: Perry RN, Moens M, Starr JL (eds) Root-knot Nematodes. CAB International, Wallingford

Oka Y, Koltai H, Bar-Eyal M, Mor M, Sharon E, Chet I, Spiegel Y (2000) New strategies for the control of plant-parasitic nematodes. Pest Manag Sci 56 : 983-988. https://doi.org/10.1002/1526-4998(200011)56:11\%3C983::AIDPS233\%3E3.0.CO;2-X

Osman HA, El-Gindi AY, Youssef MM, Ameen HH, Abd-Elbary NA, da Silva JAT, Lashein AM (2011) Protection of Pseudomonas fluorescens against the rootknot nematode, Meloidogyne incognita; role of enzyme-induced resistance in eggplant. Pest Technol 5(1):44-47

Padgham JL, Sikora RA (2007) Biological control potential and modes of action of Bacillus megaterium against Meloidogyne graminicola on rice. Crop Prot 26: 971-977. https://doi.org/10.1016/j.cropro.2006.09.004

Pathma J, Sakthivel N (2012) Microbial diversity of vermicompost bacteria that exhibit useful agricultural traits and waste management potential. SpringerPlus 1(26):1-19 http://www.springerplus.com/content/1/1/26

Pathma J, Sakthivel N (2013) Molecular and functional characterization of bacteria isolated from straw and goat manure based vermicompost. Appl Soil Ecol 70:33-47. https://doi.org/10.1016/j.apsoil.2013.03.011

Preston GM (2004) Plant perceptions of plant growth-promoting Pseudomonas. Phil Trans R Soc Lond B. 359:907-918. https://doi.org/10.1098/rstb.2003.1384

Renčo M, Kováčik P (2015) Assessment of the nematicidal potential of vermicompost, vermicompost tea, and urea application on the potato-cyst nematodes Globodera rostochiensis and Globodera pallida. J Plant Prot Res 55: 187-192. https://doi.org/10.1515/jppr-2015-0025

Rostami M, Olia M, Arabi M (2014) Evaluation of the effects of earthworm Eisenia fetida-based products on the pathogenicity of root-knot nematode 
(Meloidogyne javanica) infecting cucumber. Inter J Recycl Org Agri 3:58. https://doi.org/10.1007/s40093-014-0058-y

Saikia SK, Tiwari S, Pandey R (2013) Rhizospheric biological weapons for growth enhancement and Meloidogyne incognita management in Withania somnifera cv. Poshita. Biol Control 65:225-234. https://doi.org/10.1016/j.biocontrol.2013. 01.014

Saitou N (1988) Property and efficiency of the maximum likelihood method for molecular phylogeny. J Mol Evol 27:261-273. https://doi.org/10.1007/BF021 00082

Sánchez Ortiz I, Alvarez Lugo I, Wong Padilla I, Somontes D, Basulto Morales R, Morán Valdivia R, Mena Campos J (2018) Characterization of Cuban native bacteria isolated from nematodes as potential biological control agents for Meloidogyne spp. Rev Protección Veg 33:1-11 http://scielo.sld.cu/pdf/rpv/v33 n1/rpv04118.pdf

Schaad NW, Jones JB, Chun W (2001) Laboratory guide for the identification of plant pathogenic bacteria. In: American Phytopathological Society, 3rd edn. APS Press, St. Paul, Minn

Siddiqui IA, Ehteshamul-Haque S (2001) Suppression of the root rot-root knot disease complex by Pseudomonas aeruginosa in tomato: the influence of inoculum density, nematode populations, moisture and other plantassociated bacteria. Plant Soil 237:81-89. https://doi.org/10.1023/A:10133131 03032

Siddiqui ZA, Mahmood I (1999) Role of bacteria in the management of plant parasitic nematodes: a review. Bioresource Technol 69:167-179. https://doi. org/10.1016/S0960-8524(98)00122-9

Singh A, Singh DP, Tiwari R, Kumar K, Singh RV, Singh S, Prasanna R, Saxena AK, Nain $L$ (2015) Taxonomic and functional annotation of gut bacterial communities of Eisenia foetida and Perionyx excavatus. Microbiol Re 175:4856. https://doi.org/10.1016/j.micres.2015.03.003

Singh P, Siddiqi ZA (2010) Biocontrol of root-knot nematode Meloidogyne incognita by the isolates of Pseudomonas on tomato. Arch Phytopathol Plant Protect 43:1423-1434. https://doi.org/10.1080/03235400802536857

Singh RK, Kumar DP, Solanki MK, Singh P, Srivastva AK, Kumar S, Kashyap PL, Saxena AK, Singhal PK, Arora DK (2013) Optimization of media components for chitinase production by chickpea rhizosphere associated Lysinibacillus fusiformis B-CM18. J Basic Microbiol 53:451-460. https://doi.org/10.1002/ jobm.201100590

Tran TPH, Wang SL, Nguyen VB, Tran DM, Nguyen DS, Nguyen AD (2019) Study of novel endophytic bacteria for biocontrol of black pepper root-knot nematodes in the central highlands of Vietnam. Agronomy 9:714. https://doi. org/10.3390/agronomy9110714

Vigila V, Subramanian S, Devrajan K (2019) PGPR induced systemic resistance in tomato plants against root knot nematode, Meloidogyne incognita. J Pharmacogn Phytochem 8(25):749-752 https://www.phytojournal.com/a rchives/2019/vol8issue2S/PartT/SP-8-2-182-314.pdf

Wani AH (2015) Plant growth-promoting rhizobacteria as biocontrol agents of phytonematodes. In: Askary TH, Martinelli PRP (eds) Biocontrol Agents of Phytonematodes. CAB International, Wallingford, pp 339-364

Whitehead AG, Hemming JR (1965) A comparison of some quantitative methods of extracting small vermiform nematodes from soil. Ann Appl Biol 55:25-38. https://doi.org/10.1111/j.1744-7348.1965.tb07864x

Xi J, Qin X, Lin D, Sheng Y, Zhen S, He M, Qun X, Shan W, Hua G (2013) Identification of volatiles with nematicidal activities from Sphingobacterium nematocida ZY-71-1 and control efficiency to Meloidogyne incognita. Paper presented at Tobacco Science Research Conference, Yunnan University and CNTC Zhengzhou Tobacco Research Institute, China 2013

Xiang N, Lawrence KS, Kloepper JW, Donald PA, McInroy JA (2017a) Biological control of Heterodera glycines by spore-forming plant growth-promoting rhizobacteria (PGPR) on soybean. PLoS ONE 12(7):e0181201. https://doi.org/1 0.1371/journal.pone.0181201

Xiang N, Lawrence KS, Kloepper JW, Donald PA, McInroy JA, Lawrence GW (2017b) Biological control of Meloidogyne incognita by spore-forming plant growth-promoting Rhizobacteria on cotton. Plant Dis 101:774-784. https:// doi.org/10.1094/PDIS-09-16-1369-RE

Xiao Z, Liu M, Jiang L, Chen X, Griffiths BS, Li H, Hu F (2016) Vermicompost increases defense against root-knot nematode (Meloidogyne incognita) in tomato plants. Appl Soil Ecol 105:177-186. https://doi.org/10.1016/j.apsoil.201 6.04 .003

Yang LL, Huang Y, Liu J, Ma L, Mo MH, Li WJ, Yang FX (2012) Lysinibacillus mangiferahumi sp. nov., a new bacterium producing nematicidal volatiles. Antonie Leeuwenhoek 102:53-59. https://doi.org/10.1007/s10482-012-9712-4
Zhai Y, Shao Z, Cai M, Zheng L, Li G, Huang D, Cheng W, Thomashow LS, Weller DM, Yu Z, Zhang J (2018) Multiple modes of nematode control by volatiles of Pseudomonas putida 1 A00316 from Antarctic soil against Meloidogyne incognita. Front Microbiol 9:253. https://doi.org/10.3389/fmicb.2018.00253

\section{Publisher's Note}

Springer Nature remains neutral with regard to jurisdictional claims in published maps and institutional affiliations.

\section{Submit your manuscript to a SpringerOpen ${ }^{\circ}$ journal and benefit from:}

- Convenient online submission

- Rigorous peer review

- Open access: articles freely available online

- High visibility within the field

- Retaining the copyright to your article

Submit your next manuscript at $\boldsymbol{\nabla}$ springeropen.com 